\title{
The New Mechanistic Model to Illustrate the Complex Phenomena in Electrocoagulation Process of Vinasse
}

\author{
Iqbal Syaichurrozi $^{1,2}$, Sarto Sarto ${ }^{1 *}$, Wahyudi Budi Sediawan ${ }^{1}$, Muslikhin Hidayat ${ }^{1}$ \\ ${ }^{1}$ Department of Chemical Engineering, Faculty of Engineering, Universitas Gadjah Mada, \\ Jl. Grafika No. 2, Yogyakarta 55281, Indonesia \\ ${ }^{2}$ Department of Chemical Engineering, Faculty of Engineering, University of Sultan Ageng Tirtayasa, \\ Jl. Jendral Soedirman Km 3, Cilegon 42435, Indonesia
}

Received: 4 October 2020

Accepted: 26 November 2020

\begin{abstract}
Electrocoagulation (EC) is one of potential methods in wastewater treatments. In treating vinasse waste through EC, complex phenomena occur during EC process. Hence, previous authors have developed mechanistic models, but the models have not illustrated the phenomena completely. Therefore, the goal of this study is to build the new model of EC and apply the model to simulate the EC phenomena in treating vinasse. Many parameters (current, $\mathrm{pH}$, temperature, volume, anode weight loss, dissolved Fe concentration, chemical oxygen demand (COD) concentration, sludge mass and scum mass) are considered in developing this model. The adjustable kinetic constants in this model are $k_{c g}$, $\alpha, \beta, k_{e}, A_{f}, E_{f}$. The results show that this model can fit the measured data of EC of vinasse at various voltages (7.5 and 12.5 V) with low Sum of Squares of Errors (SSE) value (0.0784-0.2758). The voltage of $12.5 \mathrm{~V}$ results higher $k_{c g}, k_{e}, A_{f}$ and lower $E_{f}$ values than $7.5 \mathrm{~V}$.
\end{abstract}

Keywords: electrocoagulation, complex, mechanistic model, vinasse

\section{Introduction}

Electrocoagulation (EC) is one of treatment methods that are widely used to treat various wastewaters [1]. This method is successfully applied to remove organic pollutants. Compared with other methods, EC has many advantages because it needs low operating cost, produces hydrogen gas used as an alternative energy

*e-mail: sarto@ugm.ac.id and results in sludge easily separated by sedimentation and flotation [2-7].

Basically, EC consists of three conventional methods i.e. electrolysis, coagulation and flotation. In electrolysis: oxidation process occurs at anode where anode $(\mathrm{Fe})$ is dissolved to be $\mathrm{Fe}^{\mathrm{z}^{+}}$ion and reduction process occurs at cathode where the $\mathrm{H}_{2} \mathrm{O}$ is to be $\mathrm{H}_{2}$ gas and $\mathrm{OH}^{-}$ion [8]. In coagulation: chemical reaction between $\mathrm{Fe}^{\mathrm{z}}$ and $\mathrm{OH}^{-}$resulted coagulant of $\mathrm{Fe}(\mathrm{OH})_{z}$ adsorbing the pollutants to become the aggregates and then the sludge [4]. In flotation: the $\mathrm{H}_{2}$ gas pushes the sludge on the surface as scum [9]. 
For a better understanding of the EC process, currently, Syaichurrozi et al. [4] have proposed a mechanistic model of EC to illustrate the COD removal mechanism. The parameters included in the model are total COD concentration $(\mathrm{g} / \mathrm{L})$, remaining dissolved Fe concentration $(\mathrm{g} / \mathrm{L})$, sludge mass $(\mathrm{g})$, scum mass (g) and current value (A). In the model, the working volume is assumed to be constant and changes of temperature and $\mathrm{pH}$ during process are not considered. The model is successfully applied to simulate the measured data from EC process at voltage of $10 \mathrm{~V}$ with retention time of $1 \mathrm{~h}$. Furthermore, at higher voltage, the working volume decreases drastically, so it is not constant. Thus, Syaichurrozi et al. [9] have built new models to consider the change of the working volume. Besides that, they have proposed four routes for organic pollutant (expressed as chemical oxygen demand (COD)) using four mechanistic models. The results show that, the Electrocoagulation Mechanistic Model No. 2 (EMM2) results in the most precision all of the proposed models. The important points obtained by the EMM2 are that the volume is not constant, the sludge is formed by reaction between Fe and COD and then the scum is resulted by degradation of sludge. However, the EMM2 did not consider the change of $\mathrm{pH}$ and temperature during process. Factually, $\mathrm{pH}$ and temperature of solution increases during EC. Therefore, the new mechanistic model needs to be developed to simulate the complex process of EC.

The complex phenomena in EC appear when it is applied to treat waste having very high organic pollutant such as vinasse. It is a waste resulted from distillation unit as bottom product. It contains very high organic pollutant (COD) and low $\mathrm{pH}$ value. Some authors have reported studies about EC of vinasse [10-14]. The origin vinasse in the study of Yavuz [10] and Khandegar and Saroha [11] contains COD concentration of 4,750 and 3,360 mg/L respectively. Meanwhile, it in the study of Aziz et al. [14] contains COD concentration of $8,500 \mathrm{mg} / \mathrm{L}$ but in their experiment, it has been diluted to be $2,000 \mathrm{mg} / \mathrm{L}$. The extreme dilution occurred in study of Asaithambi et al. [12-13] in which the vinasse has been diluted from $80,000-90,000$ to become $2,500 \mathrm{mg} / \mathrm{L}$. The dilution way is not suggested because it will make the total volume of the waste to be very much more.

In this study, the Indonesian vinasse contains very high COD concentration (more than 100,000 mg/L). This waste is very dangerous if it discharged to the water body without treatment. Currently, the focus of this study is development of the new mechanistic model and validation of the model with experimental data of EC of vinasse at various voltages obtained from a previous study [9].

\section{Methods}

\section{Development of Kinetic Model}

\section{Anode Weight Loss}

The first reaction in EC is electrolysis. In this reaction, anode experiences oxidation, so it is sacrificed to result $\mathrm{Fe}^{z^{+}}$(Eq. 1). Meanwhile, reduction occurs in cathode in which the water is converted to $\mathrm{OH}^{-}$ion and $\mathrm{H}_{2}$ gas (Eq. 2) [15]. The rate of anode weight loss could be estimated based on Faraday's law (Eq. 3) [4]. The z value can be 2 or 3 but the appropriate $z$ value is 2 . It means that ferrous $\left(\mathrm{Fe}^{2+}\right)$ is a product of oxidation when iron is used as anode [4, 9].

$$
\begin{gathered}
\mathrm{Fe} \stackrel{\text { oxidation }}{\longrightarrow} \mathrm{Fe}^{2+}+2 \mathrm{e}^{-} \\
2 \mathrm{H}_{2} \mathrm{O}+2 \mathrm{e}^{-} \stackrel{\text { reduction }}{\longrightarrow} \mathrm{H}_{2}+2 \mathrm{OH}^{-} \\
\frac{d m_{\text {anode }}}{d t}=-\frac{I B M_{F e}}{z F}=-\frac{J A_{e} B M_{F e}}{z F}
\end{gathered}
$$

\section{Net Rate of Dissolved Fe Mol Production}

Based on Eq. 1, oxidation occurs in anode and the product of the reaction is $\mathrm{Fe}^{2+}$. Furthermore, the $\mathrm{Fe}^{2+}$ will undergo hydrolysis reaction to be $\mathrm{Fe}(\mathrm{OH})^{+}, \mathrm{Fe}(\mathrm{OH})_{2}{ }^{0}$, $\mathrm{Fe}(\mathrm{OH})_{2(\mathrm{~s})}, \mathrm{Fe}(\mathrm{OH})_{3}{ }^{-}[8]$. Therefore, for simplification of the model, in assumption, there are only the two species exist in the solution which are $\mathrm{Fe}^{2+}$ and $\mathrm{Fe}(\mathrm{OH})_{2(\mathrm{~s})}$. Equilibrium between the two iron species is shown in Eq. 4.

$$
\mathrm{Fe}(\mathrm{OH})_{2} \stackrel{\mathrm{K}_{\mathrm{s}}}{\leftrightarrow} \mathrm{Fe}^{2+}+2 \mathrm{OH}^{-}
$$

The solubility of $\mathrm{Fe}(\mathrm{OH})_{2}$ (based on Eq. 4) is expressed by Eq. 5 .

$$
K_{S}=\left[\mathrm{Fe}^{2+}\right]\left[\mathrm{OH}^{-}\right]^{2}
$$

Because of $\left[\mathrm{OH}^{-}\right]=\frac{K_{w}}{\left[\mathrm{H}^{+}\right]}=K_{w} 10^{p H}$, Eq. 5 is rearranged to Eq. 6.

$$
\begin{gathered}
K_{s}=\left[F e^{2+}\right] K_{w}{ }^{2} 10^{2 p H} \\
{\left[F e^{2+}\right]=[F e]_{s a t}=\frac{K_{S}}{K_{w}{ }^{2} 10^{2 p H}}} \\
n F e_{s a t}=\frac{K_{S}}{K_{w}{ }^{2} 10^{2 p H}} v
\end{gathered}
$$

Production of dissolved Fe mol by electrodissolution in anode during EC could be predicted by Faraday's law (Eq. 9) 


$$
\frac{d n F e_{d}}{d t}=\frac{I}{z F}=\frac{J A_{e}}{z F}
$$

Furthermore, after saturation, $\mathrm{Fe}(\mathrm{OH})_{2(s)}$ is formed and acts as coagulant to remove pollutant to make sludge. The production rate of $\mathrm{Fe}(\mathrm{OH})_{2(\mathrm{~s})}$ mol is predicted by Eq. 10 (adapted from [16]).

$$
\begin{aligned}
& \frac{d n F e(\mathrm{OH})_{2}}{d t}=k_{c g}\left(n F e_{d}-n F e_{s a t}\right) \\
& \frac{d n F e(\mathrm{OH})_{2}}{d t}=k_{c g}\left(n F e_{d}-\frac{K_{s}}{K_{w}{ }^{2} 10^{2 p H}} v\right)
\end{aligned}
$$

Therefore, the net rate of $\mathrm{Fe}^{2+}$ mol production could be written through Eq. 11.

$$
\frac{d n F e_{d}}{d t}=\underbrace{\frac{J A_{e}}{z F}}_{\text {electrodissolution }}-\underbrace{k_{c g}\left(n F e_{d}-\frac{K_{s}}{K_{w}^{2} 10^{2 p H}} v\right)}_{\text {coagulation formation }}
$$

Because of inconstant working volume during EC, the Eq. 11 is modified to Eq. 12.

$$
\begin{aligned}
& \frac{d\left([F e]_{d} v\right)}{d t}=\frac{J A_{e}}{z F}-k_{c g}\left(n F e_{d}-\frac{K_{s}}{K_{w}{ }^{2} 10^{2 p H}} v\right) \\
& {[F e]_{d} \frac{d v}{d t}+v \frac{d[F e]_{d}}{d t}=\frac{J A_{e}}{z F}-k_{c g}\left([F e]_{d} v-\frac{K_{S}}{K_{w}{ }^{2} 10^{2 p H}} v\right)} \\
& {[F e]_{d} v^{\prime}+v \frac{d[F e]_{d}}{d t}=\frac{J A_{e}}{z F}-k_{c g}\left([F e]_{d}-\frac{K_{S}}{K_{w}{ }^{2} 10^{2 p H}}\right) v} \\
& \frac{d[F e]_{d}}{d t}=\frac{\frac{J A_{e}}{z F}-k_{c g}\left([F e]_{d}-\frac{K_{S}}{K_{w}{ }^{2} 10^{2 p H}}\right) v-[F e]_{d} v^{\prime}}{v}
\end{aligned}
$$

\section{Net Rate of $\mathrm{Fe}(\mathrm{OH})_{2}$ Mass Production}

The production rate of $\mathrm{Fe}(\mathrm{OH})_{2}$ mol is shown in Eq. 10. Furthermore, it is rearranged in mass unit (Eq. 13).

$$
\frac{d m F e(O H)_{2}}{d t}=B M_{F e(O H) 2} k_{c g}\left([F e]_{d}-\frac{K_{S}}{K_{w}{ }^{2} 10^{2 p H}}\right) v
$$

Furthermore, the coagulant will adsorb the COD to make sludge [4, 9]. The adsorption reaction is assumed as Eq. 14.

$$
\mathrm{Fe}(\mathrm{OH})_{2}+\mathrm{COD} \stackrel{\mathrm{k}_{\mathrm{a}}}{\rightarrow} 2 \text { Sludge }
$$

This model assumes that adsorption reaction occurs between coagulant and COD in mass unit, not in mol unit. Based on Eq. 14, the consumption rate of coagulant mass could be written by Eq. 15 .

$$
\frac{d m F e(\mathrm{OH})_{2}}{d t}=-k_{a} C_{\mathrm{Fe}(\mathrm{OH}) 2} C_{\mathrm{COD}} v
$$

Therefore, the net rate of coagulant mass production is written by Eq. 16.

$$
\begin{aligned}
\frac{d m F e(\mathrm{OH})_{2}}{d t}= & B M_{\mathrm{Fe}(\mathrm{OH}) 2} k_{c g}\left([\mathrm{Fe}]_{d}-\frac{K_{S}}{K_{w}{ }^{2} 10^{2 p H}}\right) v \\
& -k_{a} C_{\mathrm{Fe}(\mathrm{OH}) 2} C_{\mathrm{COD}} v
\end{aligned}
$$

In assumption, the coagulant (precipitate of $\mathrm{Fe}(\mathrm{OH})_{2}$ ) does not remain in solution because it is to become sludge and scum completely, so $\frac{d m F e(O H)_{2}}{d t}=0$.

$$
\begin{aligned}
& 0=B M_{\mathrm{Fe}(\mathrm{OH}) 2} k_{c g}\left([\mathrm{Fe}]_{d}-\frac{K_{S}}{K_{w}{ }^{2} 10^{2 p H}}\right) v-k_{a} C_{F e(\mathrm{OH}) 2} C_{\mathrm{COD}} v \\
& k_{a} C_{\mathrm{Fe}(\mathrm{OH}) 2} C_{\mathrm{COD}} v=B M_{\mathrm{Fe}(\mathrm{OH}) 2} k_{c g}\left([\mathrm{Fe}]_{d}-\frac{K_{S}}{K_{w}{ }^{2} 10^{2 p H}}\right) v \\
& C_{\mathrm{Fe}(\mathrm{OH}) 2}=\frac{B M_{\mathrm{Fe}(\mathrm{OH}) 2} k_{c g}\left([\mathrm{Fe}]_{d}-\frac{K_{S}}{K_{w}{ }^{2} 0^{2 p H}}\right) v}{k_{a} C_{C O D} v}
\end{aligned}
$$

\section{Net Rate of COD Mass Consumption}

Based on Eq. 14, the consumption rate of COD mass could be written by Eq. 18 .

$$
\frac{d m C O D}{d t}=-k_{a} C_{F e(O H) 2} C_{C O D} v
$$

Entrapment reaction also occurs in sludge formation [4, 9]. Thus, Eq. 18 is extended to Eq. 19.

$$
\frac{d m C O D}{d t}=-\underbrace{k_{a} C_{F e(O H) 2} C_{C O D} v}_{\text {adsorption }}-\underbrace{k_{e} C_{C O D} v}_{\text {entrapment }}
$$

Substitute Eq. 17 to Eq. 19 to build Eq. 20.

$\frac{d m C O D}{d t}=-k_{a} \frac{B M_{F e(O H) 2} k_{C g}\left([F e]_{d}-\frac{K_{S}}{K_{w}{ }^{2} 10^{2 p H}}\right) v}{k_{a} C_{C O D}} C_{C O D} v-k_{e} C_{C O D} v$
$\frac{d m C O D}{d t}=-B M_{F e(O H) 2} k_{C g}\left([F e]_{d}-\frac{K_{S}}{K_{w}{ }^{2} 10^{2 p H}}\right) v-k_{e} C_{C O D} v$

Because of inconstant working volume, Eq. 20 is rearranged to Eq. 21.

$$
\begin{aligned}
& \frac{d\left(C_{C O D} v\right)}{d t}=-B M_{F e(O H) 2} k_{c g}\left([F e]_{d}-\frac{K_{S}}{K_{w}{ }^{2} 10^{2 p H}}\right) v-k_{e} C_{C O D} v \\
& C_{C O D} \frac{d v}{d t}+v \frac{d C_{C O D}}{d t}=-B M_{F e(O H) 2} k_{C g}\left([F e]_{d}-\frac{K_{S}}{K_{w}{ }^{2} 10^{2 p H}}\right) v-k_{e} C_{C O D} v \\
& \frac{d C_{C O D}}{d t}=\frac{-B M_{F e(O H) 2} k_{c g}\left([F e]_{d}-\frac{K_{S}}{K_{w}{ }^{2} 10^{2 p H}}\right) v-k_{e} C_{C O D} v-C_{C O D} v^{\prime}}{v}
\end{aligned}
$$

\section{Net Rate of Sludge Mass Production}

The sludge mass is resulted from reactions of adsorption and entrapment. Meanwhile, the sludge mass consumption rate is caused by scum formation (Eq. 22) 
$[4,9]$. Therefore, the net rate of sludge mass production is expressed by Eq. 23.

$$
\begin{gathered}
\text { Sludge } \stackrel{\mathrm{k}_{\mathrm{f}}}{\rightarrow} \text { Scum } \\
\frac{d m_{\text {sludge }}}{d t}=2 B M_{\mathrm{Fe}(\mathrm{OH}) 2} k_{c g}\left([\mathrm{Fe}]_{d}-\frac{K_{S}}{K_{w}{ }^{2} 10^{2 p H}}\right) v \\
+k_{e} C_{\mathrm{COD}} v-\underbrace{k_{f} m_{\text {sludge }}}_{\text {flotation }}
\end{gathered}
$$

\section{Net Rate of Scum Mass Production}

Based on Eq. 22, the scum is formed by flotation. Therefore, the net rate of scum mass production is expressed by Eq. 24.

$$
\frac{d m_{\text {scum }}}{d t}=k_{f} m_{\text {sludge }}
$$

\section{Mechanistic Model with Temperature Dependence}

For assumption of no temperature dependence, the mathematic equations included in the model are Eqs. 3, 12, 21, 23, 24. However, in the fact, solution temperature changes as function of time. Therefore, mathematic equations (in Eqs 3, 12, 21, 23, 24) have to be modified by considering the temperature change during EC process. The kinetic constants are $k_{c g}, K_{s}$, $K_{w}, k_{e}$ and $k_{f}$ Chemical process is much more affected by temperature than physical process. The kinetic constants contributing in chemical processes are $K_{s}, K_{w}$ and $k_{f}$ and those in physical processes are $k_{c g}$ and $k_{e}$. Hence, the $K_{s}, K_{w}$ and $k_{f}$ are modified with consideration of temperatur change and $k_{c g}$ and $k_{e}$ are assumed not affected by temperature change.

The equilibrium constants $\left(K_{s}\right.$ and $\left.K_{w}\right)$ are modified through Van't Hoff equation. The Van't Hoff equation as function of temperature for $K_{s}$ is shown by Eq. 25 [17].

$$
\ln \frac{K_{S}}{K_{S 0}}=\frac{-\Delta H_{S}}{R}\left(\frac{1}{T}-\frac{1}{T_{0}}\right)
$$

Furthermore, Eq. 25 is rearranged to Eq. 26.

$$
\begin{aligned}
& \ln \frac{K_{S}}{K_{S 0}}=\frac{\Delta H_{S}}{R T_{0}}-\frac{\Delta H_{S}}{R T} \\
& \frac{K_{S}}{K_{S 0}}=\exp \left(\frac{\Delta H_{S}}{R T_{0}}\right) \exp \left(-\frac{\Delta H_{S}}{R T}\right) \\
& K_{S}=K_{S 0} \exp \left(\frac{\Delta H_{S}}{R T_{0}}\right) \exp \left(-\frac{\Delta H_{S}}{R T}\right)
\end{aligned}
$$

Assuming that $K_{s 0} \exp \left(\frac{\Delta H_{s}}{R T_{0}}\right)=K_{s 0}{ }^{\prime}$, so Eq. 26 is modified to Eq. 27.

$$
K_{s}=K_{s 0}{ }^{\prime} \exp \left(-\frac{\Delta H_{s}}{R T}\right)
$$

By the same way with $K_{s}$, the $K_{w}$ is modified to Eq. 28.

$$
K_{w}=K_{w 0}^{\prime} \exp \left(-\frac{\Delta H_{w}}{R T}\right)
$$

Therefore,

$$
\begin{aligned}
\frac{K_{S}}{K_{W}{ }^{2}} & =\frac{K_{s 0^{\prime}} \exp \left(-\frac{\Delta H_{S}}{R T}\right)}{\left(K_{w 0^{\prime}} \exp \left(-\frac{\Delta H_{w}}{R T}\right)\right)^{2}}=\frac{K_{S 0^{\prime}}}{\left(K_{\left.w 0^{\prime}\right)^{2}}\right.} \exp \left(\frac{-\Delta H_{S}-2\left(-\Delta H_{w}\right)}{R T}\right) \\
\frac{K_{S}}{K_{w}{ }^{2}} & =\alpha \exp \left(\frac{\beta}{R T}\right)
\end{aligned}
$$

with:

$$
\begin{gathered}
\alpha=\frac{K_{s 0^{\prime}}}{\left(K_{\left.w 0^{\prime}\right)^{2}}\right.} \\
\beta=-\Delta H_{s}-2\left(-\Delta H_{w}\right)
\end{gathered}
$$

Furthermore, the $k_{f}$ is modified through Arrhenius equation (Eq. 32) [18].

$$
k_{f}=A_{f} \exp \left(-\frac{E_{f}}{R T}\right)
$$

Substitution Eqs 29 and 32 to Eqs 3, 12, 21, 23 and 24 to get new mathematical equations and then shown in Table 1.

The summary of the final mathematic equations is shown in Table 1. The change of current density, $\mathrm{pH}$ and temperature profile is approached by using an empirical curve (see section 5.1). The change of working volume during EC is identified by the change of vinasse surface $(x)$ in reactor. Also, the value of $x$ is approached by using an empirical curve (see section 5.1). Furthermore, the values of $A_{e}, v$ and $v^{\prime}$ is calculated by using formulas shown in Table 1 [9].

\section{Simulation}

The adjustable kinetic constants in this model are $k_{c g}, \alpha, \beta, k_{e}, A_{f}, E_{f}$. The values of the constants are obtained by minimization of SSE (Sum of Squared Error) (Eq. 33). The model (simultaneous ordinary differential equations, Table 1) is solved using MATLAB program with ode15s solver and minimizing SSE with fminsearch [9].

$$
\begin{gathered}
\text { Sum of Squares of Errors (SSE) } \\
=\sum_{i=1}^{n}\left(\frac{\text { measureddata-predicteddata }}{\text { measureddata }}\right)^{2}
\end{gathered}
$$

\section{Experimental Data}

The experimental data used to validate the model are obtained from a previous study [9]. The data is obtained from EC experiment using a lab-scale-batch 
Table 1. Summary of mathematic equations for the mechanistic model with temperature dependence.

\begin{tabular}{|c|c|}
\hline Rate & Mathematic Equation \\
\hline$\frac{d m_{\text {anode }}}{d t}$ & $-\frac{J A_{e} B M_{F e}}{z F}$ \\
\hline \multirow[t]{2}{*}{$\frac{d[\mathrm{Fe}]_{d}}{d t}$} & $\frac{J A_{e}}{Z F}-k_{c g}\left([F e]_{d}-\frac{\alpha \exp \left(\frac{\beta}{R T}\right)}{10^{2 p H}}\right) v-[F e]_{d} v^{\prime}$ \\
\hline & $v$ \\
\hline \multirow[t]{2}{*}{$\frac{d C_{C O D}}{d t}$} & $-B M_{F e(O H) 2} k_{c g}\left([F e]_{d}-\frac{\alpha \exp \left(\frac{\beta}{R T}\right)}{10^{2 p H}}\right) v-k_{e} C_{C O D} v-C_{C O D} v^{\prime}$ \\
\hline & $v$ \\
\hline$\frac{d m_{\text {sludge }}}{d t}$ & $2 B M_{F e(O H) 2} k_{c g}\left([F e]_{d}-\frac{\alpha \exp \left(\frac{\beta}{R T}\right)}{10^{2 p H}}\right) v+k_{e} C_{C O D} v-A_{f} \exp \left(-\frac{E_{f}}{R T}\right) m_{\text {sludge }}$ \\
\hline$\frac{d m_{\text {scum }}}{d t}$ & $A_{f} \exp \left(-\frac{E_{f}}{R T}\right) m_{\text {sludge }}$ \\
\hline$J, p H, T, x$ & $f(t)$ \\
\hline$A_{e}$ & $2\left(l_{e}-x\right) w_{e}+2\left(l_{e}-x\right) t_{e}+w_{e} t_{e}$ \\
\hline$v$ & $v_{0}-A_{R} x$ \\
\hline$v^{\prime}$ & $\frac{d v}{d t}$ \\
\hline
\end{tabular}

reactor with cylindrical shape having diameter 1.1 $\mathrm{dm}$ and height of $1.55 \mathrm{dm}$. Iron is used as anode and cathode with active dimension of length, width, thickness of $0.95,0.3,0.03 \mathrm{dm}$ respectively. The value of inter-electrode is maintained to be constant in $0.55 \mathrm{dm}$. The voltage is varied to be $7.5 \mathrm{~V}$ and $12.5 \mathrm{~V}$. The measured parameters were total COD concentration $\left(\mathrm{g} / \mathrm{dm}^{3}\right)$, remaining dissolved $\mathrm{Fe}\left(\mathrm{g} / \mathrm{dm}^{3}\right)$, sludge mass $(\mathrm{g})$, scum mass $(\mathrm{g})$, current $(\mathrm{A}), x(\mathrm{dm})$, temperature $(\mathrm{K})$, anode weight $(\mathrm{g})$. The complete data is shown in Table 2. Because the unit of dissolved Fe in the model is $\mathrm{mol} / \mathrm{dm}^{3}$, the dissolved $\mathrm{Fe}\left(\mathrm{g} / \mathrm{dm}^{3}\right)$ in Table 2 is converted to unit of $\mathrm{mol} / \mathrm{dm}^{3}$ by divided it with $\mathrm{BM}$ of Fe $(56 \mathrm{~g} / \mathrm{mol})$.

\section{Results and Discussions}

Empirical Equation for $\mathrm{pH}, \mathrm{T}, x, \mathrm{~J}$

The solution $\mathrm{pH}$ changes during EC process (Table 2) because of $\mathrm{OH}^{-}$accumulation in solution. It is resulted from reduction at cathode (Eq.2). The $\mathrm{pH}$ solution in vinasse increases faster at voltage of $12.5 \mathrm{~V}$ than at $7.5 \mathrm{~V}$ because the current value at the former is higher than that at the later (Table 2). The mol amount of $\mathrm{OH}^{-}$ion is directly proportional with current value.
From Fig. 1a), mathematic equations between $\mathrm{pH}$ and electrolysis time at 7.5 and $12.5 \mathrm{~V}$ are obtained as:

$$
\begin{aligned}
p H_{7.5 V} & =8 \times 10^{-8} t^{2}+5 \times 10^{-5} t \\
& +6.004\left(\mathrm{R}^{2}=0.988\right) \\
p H_{12.5 V} & =-2 \times 10^{-7} t^{2}+1 \times 10^{-3} t \\
& +5.811\left(\mathrm{R}^{2}=0.932\right)
\end{aligned}
$$

Similar with solution $\mathrm{pH}$, the solution temperature increases until the end of process. It has a correlation with current. The energy supplied from electrolysis can be estimated using formula in Eq.36. Furthermore, the energy received by the solution can be estimated using Eq. 37.

$$
\begin{aligned}
& Q=V I t \\
& Q=C_{p} \Delta T
\end{aligned}
$$

Clearly, the increase in temperature is caused by supply of current continuously in solution during process. From Fig. 1b), mathematic equations between temperature and electrolysis time at 7.5 and $12.5 \mathrm{~V}$ are obtained as: 
Table 2. Experimental data during EC of vinasse waste at various voltages [9].

\begin{tabular}{|c|c|c|c|c|c|c|c|c|c|c|}
\hline \multicolumn{11}{|c|}{$7.5 \mathrm{~V}$} \\
\hline $\begin{array}{l}\mathrm{t} \\
(\mathrm{s})\end{array}$ & $\begin{array}{c}\mathrm{I} \\
\text { (A) }\end{array}$ & $\begin{array}{c}\mathrm{T} \\
(\mathrm{K})\end{array}$ & $\mathrm{pH}$ & $\begin{array}{c}x \\
(\mathrm{dm})\end{array}$ & $\begin{array}{l}\text { Scum } \\
(\mathrm{g})\end{array}$ & $\begin{array}{l}\mathrm{COD} \\
\left(\mathrm{g} / \mathrm{dm}^{3}\right)\end{array}$ & $\begin{array}{l}\text { Dissolved Fe } \\
\left(\mathrm{g} / \mathrm{dm}^{3}\right)\end{array}$ & $\begin{array}{c}\text { Dissolved Fe } \\
\left(\mathrm{mol} / \mathrm{dm}^{3}\right)\end{array}$ & $\begin{array}{l}\text { Anode weight } \\
\text { loss }(\mathrm{g})\end{array}$ & $\mathrm{J}\left(\mathrm{A} / \mathrm{dm}^{2}\right)$ \\
\hline 0 & 2.15 & 302.65 & 6.0 & 0.000 & 0.00 & 100.16 & 0.039 & 0.000693 & 0 & 3.38 \\
\hline 600 & 2.16 & 304.15 & 6.1 & 0.020 & 0.28 & 97.36 & $\mathrm{Na}$ & $\mathrm{Na}$ & $\mathrm{Na}$ & 3.47 \\
\hline 1200 & 2.20 & 306.65 & 6.1 & 0.045 & 1.42 & 92.87 & 0.398 & 0.007112 & $\mathrm{Na}$ & 3.63 \\
\hline 1800 & 2.22 & 307.35 & 6.4 & 0.065 & 2.78 & 92.65 & $\mathrm{Na}$ & $\mathrm{Na}$ & $\mathrm{Na}$ & 3.74 \\
\hline 2400 & 2.18 & 308.65 & 6.6 & 0.085 & 4.05 & 92.65 & 0.923 & 0.016483 & $\mathrm{Na}$ & 3.76 \\
\hline 3000 & 2.10 & 309.65 & 6.8 & 0.105 & 5.30 & 91.08 & $\mathrm{Na}$ & $\mathrm{Na}$ & $\mathrm{Na}$ & 3.71 \\
\hline 3600 & 2.05 & 310.15 & 7.2 & 0.125 & 6.90 & 91.08 & 0.886 & 0.015817 & -2.241 & 3.70 \\
\hline \multicolumn{11}{|c|}{$12.5 \mathrm{~V}$} \\
\hline $\begin{array}{l}\mathrm{t} \\
(\mathrm{s})\end{array}$ & $\begin{array}{c}\mathrm{I} \\
\text { (A) }\end{array}$ & $\begin{array}{c}\mathrm{T} \\
(\mathrm{K})\end{array}$ & $\mathrm{pH}$ & $\begin{array}{c}x \\
(\mathrm{dm})\end{array}$ & $\begin{array}{l}\text { Scum } \\
(\mathrm{g})\end{array}$ & $\begin{array}{l}\mathrm{COD} \\
\left(\mathrm{g} / \mathrm{dm}^{3}\right)\end{array}$ & $\begin{array}{l}\text { Dissolved Fe } \\
\left(\mathrm{g} / \mathrm{dm}^{3}\right)\end{array}$ & $\begin{array}{c}\text { Dissolved Fe } \\
\left(\mathrm{mol} / \mathrm{dm}^{3}\right)\end{array}$ & $\begin{array}{c}\text { Anode weight } \\
\text { loss }(\mathrm{g})\end{array}$ & $\mathrm{J}\left(\mathrm{A} / \mathrm{dm}^{2}\right)$ \\
\hline 0 & 3.76 & 302.15 & 6.0 & 0.000 & 0.00 & 100.16 & 0.039 & 0.000693 & 0 & 5.91 \\
\hline 600 & 4.17 & 308.65 & 6.3 & 0.090 & 1.54 & 95.79 & $\mathrm{Na}$ & $\mathrm{Na}$ & $\mathrm{Na}$ & 7.23 \\
\hline 1200 & 4.25 & 314.65 & 6.8 & 0.160 & 5.32 & 92.65 & 0.560 & 0.009997 & $\mathrm{Na}$ & 8.01 \\
\hline 1800 & 4.26 & 319.85 & 7.5 & 0.215 & 9.47 & 91.08 & $\mathrm{Na}$ & $\mathrm{Na}$ & $\mathrm{Na}$ & 8.62 \\
\hline 2400 & 4.08 & 324.35 & 7.7 & 0.275 & 14.44 & 87.94 & 0.529 & 0.009447 & $\mathrm{Na}$ & 8.98 \\
\hline 3000 & 3.88 & 328.15 & 7.7 & 0.375 & 19.35 & 84.80 & $\mathrm{Na}$ & $\mathrm{Na}$ & $\mathrm{Na}$ & 9.99 \\
\hline 3600 & 3.53 & 330.65 & 7.3 & 0.440 & 26.78 & 83.17 & 0.490 & 0.008748 & -4.328 & 10.21 \\
\hline
\end{tabular}

$$
\begin{aligned}
T_{7.5 V}= & -4 \times 10^{-7} t^{2}+3 \times 10^{-3} t \\
& +302.5\left(\mathrm{R}^{2}=0.991\right) \\
T_{12.5 V}= & -1 \times 10^{-6} t^{2}+1.1 \times 10^{-2} t \\
& +302\left(\mathrm{R}^{2}=0.999\right)
\end{aligned}
$$

The surface of vinasse in reactor decreases because reduction reaction of water, evaporation of water and scum formation [9]. Fig. 1c) shows the mathematic equation between $x$ and electrolysis time with detailed equations for 7.5 and $12.5 \mathrm{~V}$ as:

$$
\begin{gathered}
x_{7.5 V}=3.51 \times 10^{-5} t\left(\mathrm{R}^{2}=0.998\right) \\
x_{12.5 V}=12.21 \times 10^{-5} t\left(\mathrm{R}^{2}=0.993\right)
\end{gathered}
$$

Furthermore, current density profile during process is function electrolysis time shown by Fig. 1d) with detailed equations as:

$$
\begin{aligned}
J_{7.5 V}= & -6 \times 10^{-8} t^{2}+2.9 \times 10^{-4} t \\
& +3.356\left(\mathrm{R}^{2}=0.958\right) \\
J_{12.5 V}= & -2 \times 10^{-7} t^{2}+1.72 \times 10^{-3} t \\
& +6.058\left(\mathrm{R}^{2}=0.985\right)
\end{aligned}
$$

All the empirical equations (Eqs 34-35 and 38-43) are used in the mechanistic model having mathematic equations shown on Table 1. The equations show that complex phenomena occur during EC process because $\mathrm{pH}, \mathrm{T}, x$ and $\mathrm{J}$ change as function of time. Furthermore, the changes of anode weight, COD concentration, dissolved $\mathrm{Fe}$ concentration, scum mass and sludge mass are predicted using the mechanistic model and the results are discussed in section 5.2.

\section{Application of the New Model}

The new mechanistic model successfully simulates the behavior of COD removal during EC of vinasse with very low SSE value (0.0784-0.2758, Table 3). The visualization between experiment and predicted data is depicted in Fig. 2(a-e). Also, the kinetic constants are shown in Table 3 in detail.

\section{Anode Weight Loss and Dissolved Fe}

Anode weight loss is successfully predicted by Faraday's law with $\mathrm{z}=2$ (Fig. 2a). This value confirms that the product of oxidation is $\mathrm{Fe}^{2+}$. Furthermore, Fig. 2b) shows the remaining dissolved Fe in solution. It in vinasse during $\mathrm{EC}$ at $12.5 \mathrm{~V}$ is less than at $7.5 \mathrm{~V}$. It is related to solution $\mathrm{pH}$ where the higher the $\mathrm{pH}$, the low solubility of Fe. Hence, the solubility of Fe at 

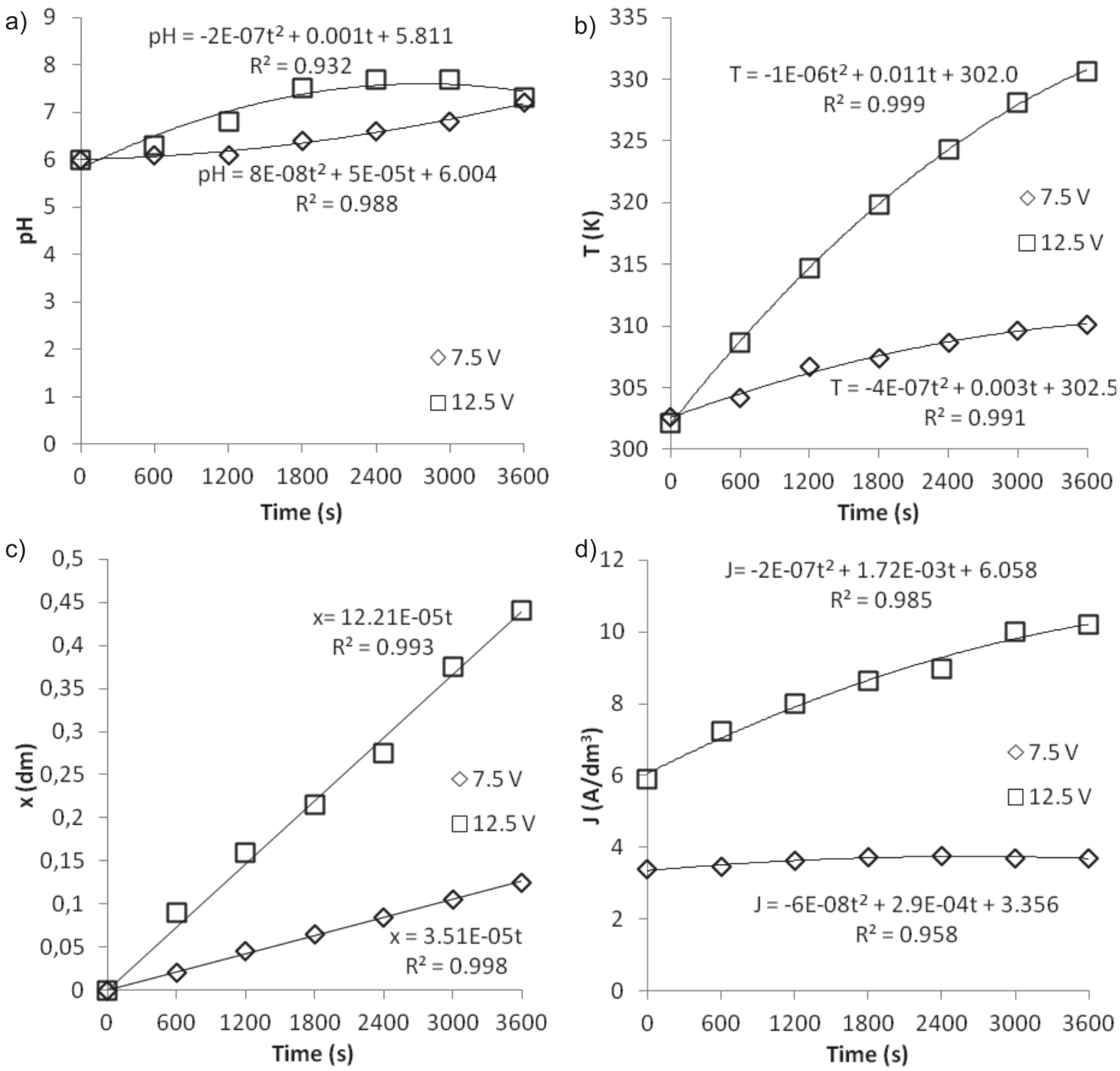

Fig. 1. The empirical equation for changes of a) solution $\mathrm{pH}, \mathrm{b}$ ) solution temperature, c) surface vinasse in reactor and d) current density

12.5 $\mathrm{V}$ is lower than at $7.5 \mathrm{~V}$ because the former increases the $\mathrm{pH}$ more rapidly. The solubility is also affected by solution temperature. In theory, higher temperature will result higher solubility. In the fact, voltage of $12.5 \mathrm{~V}$ results lower solubility of Fe although it results solution temperature higher than $7.5 \mathrm{~V}$. Hence, the solubility of Fe in vinasse is mainly affected by $\mathrm{pH}$, not temperature.

The $k_{c g}$ presents the rate of coagulant formation. This kinetic constant is affected by the solubility of $\mathrm{Fe}$ and current value. The current value at $12.5 \mathrm{~V}$ is higher than that at $7.5 \mathrm{~V}$ (Table 2). The higher the current value, the more the $\mathrm{Fe}^{2+}$ mol is resulted from oxidation reaction. Hence, total $\mathrm{Fe}^{2+} \mathrm{mol}$ at $12.5 \mathrm{~V}$ is higher than that at $7.5 \mathrm{~V}$. Meanwhile, the solubility of $\mathrm{Fe}$ at $12.5 \mathrm{~V}$ is lower, so much more coagulant is formed at this voltage than the lower voltage. The $k_{c g}$ in $12.5 \mathrm{~V}\left(3.20 \times 10^{-3} / \mathrm{s}\right)$ is higher than that in $7.5 \mathrm{~V}\left(8.06 \times 10^{-4} / \mathrm{s}\right)$.

The constants of $\alpha$ and $\beta$ for $7.5 \mathrm{~V}$ is almost same with those for $12.5 \mathrm{~V}$. This shows that enthalpy process is not affected significantly by temperature change. This is in line with Van't Hoff assumption in which the enthalpy process is no temperature dependence.

\section{COD Concentration}

The profile of decrease in COD concentration is also successfully predicted by the new model (Fig. 2c). Based on explanation in section 5.2.1, voltage of $12.5 \mathrm{~V}$ results more coagulant than $7.5 \mathrm{~V}$, so the former can remove the COD in larger amount than the later. Furthermore $12.5 \mathrm{~V}$ also results higher $k_{e}$ value than $7.5 \mathrm{~V}$. It means, the entrapment reaction is easier to hold when the coagulant is resulted in larger amount.

\section{Sludge and Scum Mass}

The evolution of sludge and scum mass during EC is predicted and shown in Fig. 2(d,e). Voltage of $12.5 \mathrm{~V}$ results more sludge and scum mass than $7.5 \mathrm{~V}$. 


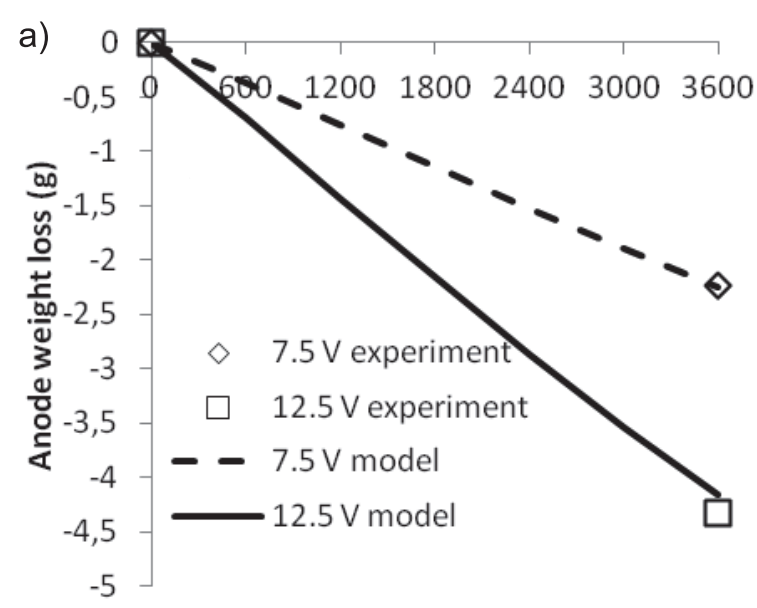

Time (s)
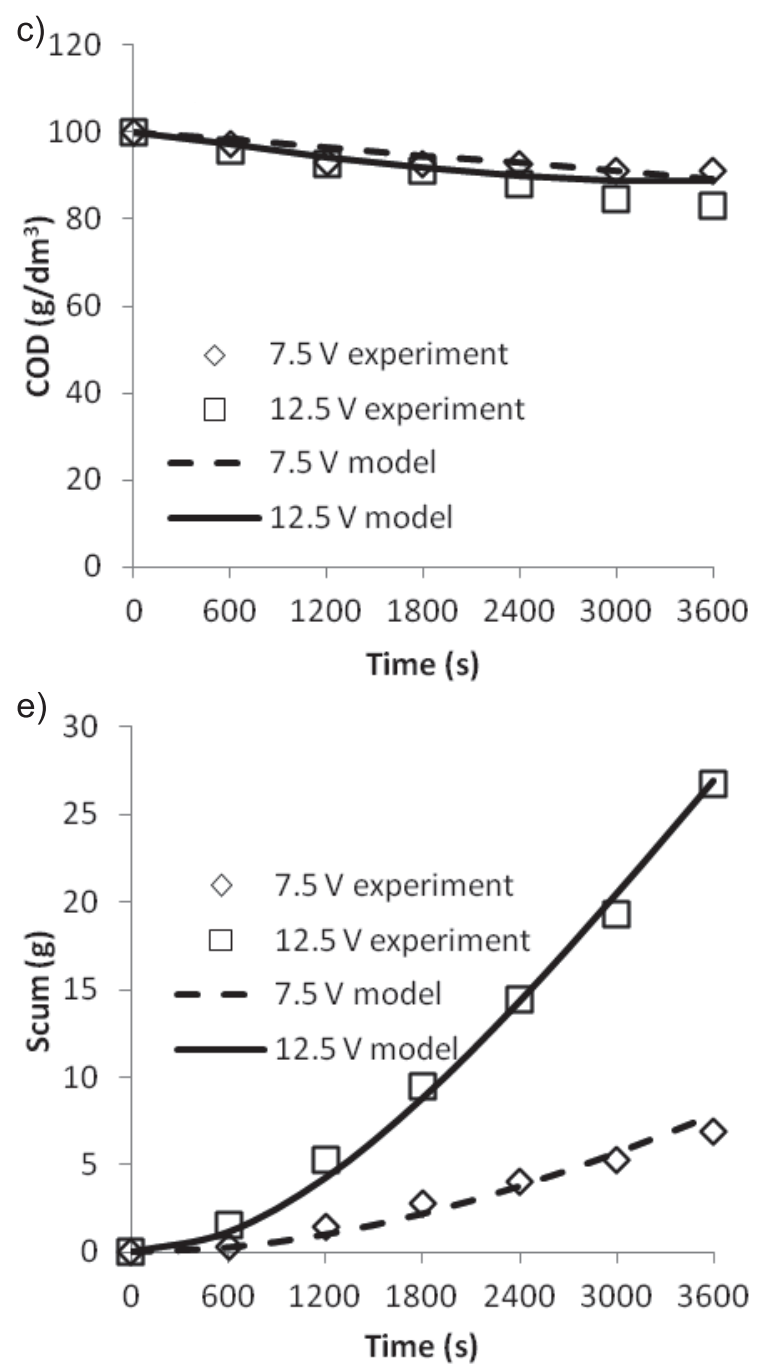

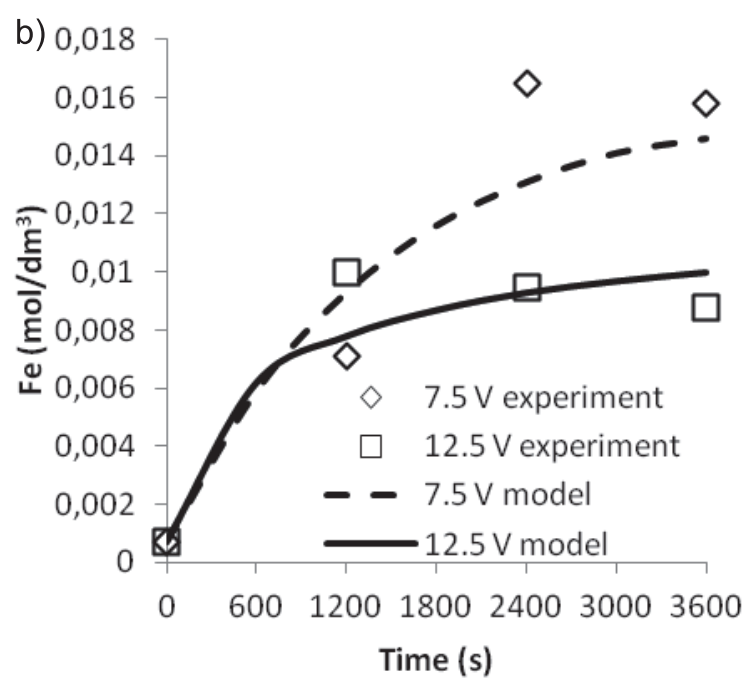

d)
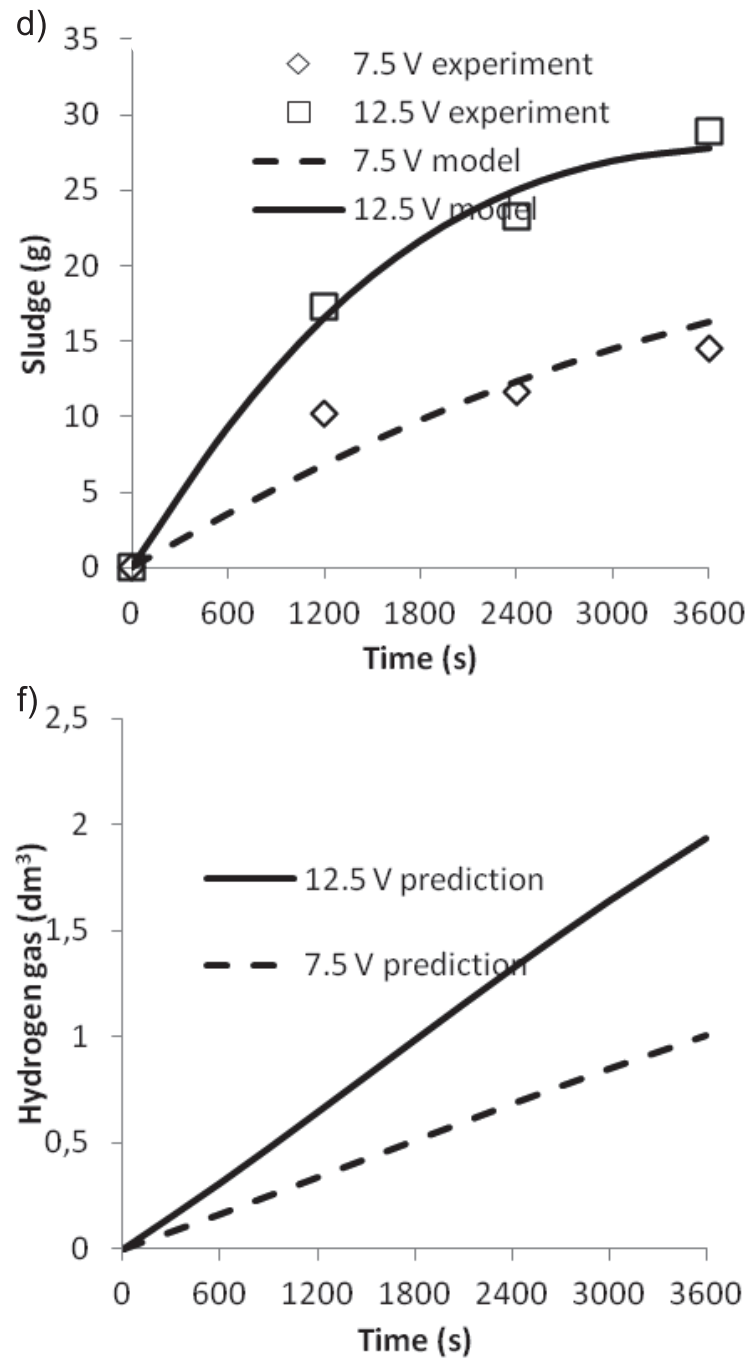

Fig. 2. Fitting between experimental and predicted data from the new kinetic model for a) anode weight loss, b) concentration of Fe, c) concentration of COD, d) mass of sludge, e) mass of scum; and then f) prediction of Hydrogen gas based on Faraday's Law.

The sludge is formed from adsorption of COD on coagulant and settles on the bottom of EC reactor. Furthermore the sludge is broken and goes to surface of vinasse as scum by evolution of $\mathrm{H}_{2}$. The production of $\mathrm{H}_{2}$ in mol unit could be predicted through Faraday's law showed in Eq. 44 [9]. The unit of $\mathrm{H}_{2}$ could be converted in $\mathrm{L}$ unit by using Eq. 45.

$$
\frac{d n_{H_{2}}}{d t}=\frac{I}{F} H=\frac{J A_{e}}{F} H=\frac{J A_{e}}{F} H
$$


Table 3. Kinetic constant values in simulation of the experimental data from EC of vinasse.

\begin{tabular}{|c|c|c|c|}
\hline Kinetic constants & Unit & $7.5 \mathrm{~V}$ & $12.5 \mathrm{~V}$ \\
\hline$k_{c g}$ & $/ \mathrm{s}$ & $8.06 \times 10^{-4}$ & $3.20 \times 10^{-3}$ \\
\hline$\alpha$ & $\mathrm{dm}^{3} / \mathrm{mol}$ & $9.02 \times 10^{3}$ & $10.5 \times 10^{3}$ \\
\hline$\beta$ & $\mathrm{J} / \mathrm{mol}$ & $8.91 \times 10^{1}$ & $9.23 \times 10^{1}$ \\
\hline$k_{e}$ & $/ \mathrm{s}$ & $5.97 \times 10^{-5}$ & $1.59 \times 10^{-4}$ \\
\hline$A_{f}$ & - & $2.35 \times 10^{-4}$ & $3.92 \times 10^{-4}$ \\
\hline$E_{f}$ & $\mathrm{~J} / \mathrm{mol}$ & $9.54 \times 10^{-5}$ & $2.01 \times 10^{-7}$ \\
\hline $\mathrm{SSE}$ & - & 0.2758 & 0.0784 \\
\hline
\end{tabular}

$$
\frac{d V_{H_{2}}}{d t}=\frac{d n_{H_{2}}}{d t} \frac{R T}{P}=\frac{J A_{e} H R T}{F P}
$$

The predicted $\mathrm{H}_{2}$ gas is presented in Fig. 2f). From the figure, voltage $12.5 \mathrm{~V}$ results $1.93 \mathrm{dm}^{3}$ and $7.5 \mathrm{~V}$ results $1.01 \mathrm{dm}^{3}$. It causes that the scum production at $12.5 \mathrm{~V}$ is more than at $7.5 \mathrm{~V}$. Table 3 shows the constants of $A_{f}$ and $E_{f}$ in which they depends on solution temperature. The frequency factor $\left(A_{f}\right)$ increases and activation energy $\left(E_{f}\right)$ decreases with increasing of voltage from 7.5 to $12.5 \mathrm{~V}$. The less the activation energy, the easier the reaction occurs. Furthermore, the frequency factor shows the collision where the higher the frequency factor, the more often the $\mathrm{H}_{2}$ and sludge collides to form scum. The high temperature forces the dissolved hydrogen to become $\mathrm{H}_{2}$ gas easily. Also, it affects the big bubble size of $\mathrm{H}_{2}$ gas. Therefore, flotation process occurs easier at $12.5 \mathrm{~V}$ than at $7.5 \mathrm{~V}$ because solution temperature at $12.5 \mathrm{~V}$ is higher.

\section{Operating Cost}

In EC process, the operating cost is to become one of important terms. The main components in operating cost are electrode, energy and chemical costs [4]. Furthermore, the common formula used to estimate the operating cost is shown in Eq. 46-48 [4].

$$
\begin{gathered}
\frac{d[\text { Operating Cost }]}{d t}=a \frac{d[\text { Energy Cost }]}{d t} \\
+b \frac{d[\text { Electrode Cost }]}{d t}+c \text { Chemical Cost } \\
\frac{d[\text { Energy Cost }]}{d t}=\frac{V I}{v_{i}} \\
\frac{d[\text { Electrode Cost }]}{d t}=\frac{J A_{e} B M_{F e}}{z F v_{i}}
\end{gathered}
$$

The $a$ is electrical energy cost with value of $30.97 \times 10^{-5} \mathrm{IDR} / \mathrm{Ws}$ (IDR per watt second), $b$ is iron material with value of $20 \mathrm{IDR} / \mathrm{g}$ and $c$ is chemical cost with value of $16 \mathrm{IDR} / \mathrm{g}$ for technical grade $\mathrm{NaOH}$ (flake) [4]. Results of calculation for operating cost are presented in Table 4. In this study, the initial $\mathrm{pH}$ of vinasse is adjusted from 4.35 to 6.0. It needed amount of $8.4558 \mathrm{~g} \mathrm{NaOH}$ with price of $135.29 \mathrm{IDR} / \mathrm{dm}^{3}$ [4]. Furthermore electrode and energy costs needed by voltage of $12.5 \mathrm{~V}$ are higher than $7.5 \mathrm{~V}$. Finally, the total operating cost for 7.5 and $12.5 \mathrm{~V}$ is 204.14 and 262.91 IDR $/ \mathrm{dm}^{3}$ respectively. Meanwhile, voltages of 7.5 and $12.5 \mathrm{~V}$ result the COD mass removal efficiency of 19.87 and $51.67 \%$ respectively (Table 4 ). Therefore, voltage of $12.5 \mathrm{~V}$ is more effective than $7.5 \mathrm{~V}$ because the former results higher ratio of COD mass removal efficiency (\%) to total operating cost (IDR/ $\mathrm{dm}^{3}$ ) (Table 4).

\section{Conclusion}

The new kinetic model of EC is successfully developed with considering of many measured parameters which are current, $\mathrm{pH}$, temperature, volume, anode weight loss, dissolved Fe concentration, COD concentration, sludge mass and scum mass. The adjustable kinetic constants in this model are $k_{c g}, \alpha, \beta$, $k_{e}, A_{f}, E_{f}$ This model can fit the measured data of EC of vinasse at various voltages with low SSE value (0.0784-0.2758). Based on simulation, voltage of 12.5 $\mathrm{V}$ resulted higher $k_{c g}, k_{e}, A_{f}$ and lower $E_{f}$ values than $7.5 \mathrm{~V}$.

Table 4. Operating cost of EC process in treating $1 \mathrm{dm}^{3}$ vinasse after $3600 \mathrm{sec}$.

\begin{tabular}{|c|c|c|c|c|c|c|}
\hline Voltage & $\begin{array}{c}\text { Electrode cost } \\
\left(\mathrm{IDR} / \mathrm{dm}^{3}\right)\end{array}$ & $\begin{array}{c}\text { Energy cost } \\
\left(\mathrm{IDR} / \mathrm{dm}^{3}\right)\end{array}$ & $\begin{array}{c}\text { Chemical cost }[4] \\
\left(\mathrm{IDR} / \mathrm{dm}^{3}\right)\end{array}$ & $\begin{array}{c}\text { Total operating cost } \\
\left(\mathrm{IDR} / \mathrm{dm}^{3}\right)\end{array}$ & $\begin{array}{c}\text { COD mass } \\
\text { removal efficiency } \\
{[9](\%)}\end{array}$ & $\begin{array}{c}\text { Ratio of COD mass } \\
\text { removal efficiency/ total } \\
\text { operating cost } \\
\left(\% / \mathrm{IDR} / \mathrm{dm}^{3}\right)\end{array}$ \\
\hline $7.5 \mathrm{~V}$ & 44.89 & 23.96 & 135.29 & 204.14 & 19.87 & 0.0973 \\
\hline $12.5 \mathrm{~V}$ & 83.21 & 44.41 & 135.29 & 262.91 & 51.67 & 0.1965 \\
\hline
\end{tabular}

Note $=$ COD removal efficiency $=\frac{\text { initial COD mass }(g)-\text { final COD mass }(g)}{\text { initial COD mass }(g)} \times 100 \%$ 


\section{Acknowledgement}

The authors thank to Universitas Gadjah Mada via Rekognisi Tugas Akhir (RTA) Program 2020 with assignment letter of 2488/UN1.P.III/DIT-LIT/PT/2020 for financial support.

\section{Conflict of Interest}

The authors declare no potential conflict of interest regarding the publication of this work.

\section{Nomenclatures}

$A_{e}$ - active surface area of electrode $\left(\mathrm{dm}^{2}\right)$

$A_{f}$ - frequency factor for flotation

$A_{R}$ - base area of EC reactor $\left(\mathrm{dm}^{2}\right)$

$B M_{F e}-$ molecular weight of $\mathrm{Fe}(56 \mathrm{~g} / \mathrm{mol})$

$\mathrm{BM}_{\mathrm{Fe}(\mathrm{OH})_{2}}-$ molecular weight of $\mathrm{Fe}(\mathrm{OH})_{2}(90 \mathrm{~g} / \mathrm{mol})$

$C_{C O D}-$ concentration of $\mathrm{COD}\left(\mathrm{g} / \mathrm{dm}^{3}\right)$

$\mathrm{C}_{\mathrm{Fe}(\mathrm{OH})_{2}}$ - concentration of $\mathrm{Fe}(\mathrm{OH})_{2}\left(\mathrm{~g} / \mathrm{dm}^{3}\right)$

$C_{p}$ - caloric capacity of solution $(\mathrm{J} / \mathrm{K})$

$d$-distance between electrodes $(\mathrm{dm})$

$E_{f}$ - activation energy for flotation $(\mathrm{J} / \mathrm{mol})$

$F$ - Faraday's constant $(96,500 \mathrm{C} / \mathrm{mol})$

$\mathrm{H}$ - number of Hydrogen molecules per electron ( $(1 / 2)$

$I$ - current (A)

$J$ - current density $\left(\mathrm{A} / \mathrm{dm}^{2}\right)$

$k_{a}$ - reaction rate constant for adsorption (/(g.s)

$k_{c g}$ - rate constant for $\mathrm{Fe}(\mathrm{OH})_{2}$ formation $(/ \mathrm{s})$

$k_{e}^{c g}$ - reaction rate constant for entrapment $(/ \mathrm{s})$

$k_{f}$ - reaction rate constant for flotation (/s)

$K_{S}$ - equilibrium constant of $\mathrm{Fe}(\mathrm{OH})_{2}\left(\mathrm{~mol}^{3} / \mathrm{dm}^{9}\right)$ at $T$

$K_{s 0}-$ equilibrium constant of $\mathrm{Fe}(\mathrm{OH})_{2}\left(\mathrm{~mol}^{3} / \mathrm{dm}^{9}\right)$ at $T_{0}$

$K_{w}$ - equilibrium constant of water $\left(\mathrm{mol}^{2} / \mathrm{dm}^{6}\right)$ at $T$

$K_{w 0}^{w}$ - equilibrium constant of water $\left(\mathrm{mol}^{2} / \mathrm{dm}^{6}\right)$ at $T_{0}$

$l_{e}$ - length of electrode $(\mathrm{dm})$

$m_{\text {anode }}-$ weight of anode $(\mathrm{g})$

$m_{C O D}-$ mass of $C O D(\mathrm{~g})$

$m_{\mathrm{Fe}(\mathrm{OH})_{2}}-$ mass of $\mathrm{Fe}(\mathrm{OH})_{2}(\mathrm{~g})$

$m_{\text {scum }}-$ mass of scum $(\mathrm{g})$

$m_{\text {sludge }}-$ mass of sludge $(\mathrm{g})$

$n F e_{\text {sat }}-$ mol of $\mathrm{Fe}^{2+}$ at saturation (mol)

$n \mathrm{Fe}(\mathrm{OH})_{2}-\mathrm{mol}$ of $\mathrm{Fe}(\mathrm{OH})_{2}(\mathrm{~mol})$

$n \mathrm{Fe}_{d}-$ mol of total dissolved $\mathrm{Fe}^{2+}$ (mol)

$n_{\mathrm{H}_{2}}$ - Hydrogen amount (mol)

$P$ - Pressure (atm)

$Q$ - energy (J)

$R$ - ideal gas constant $(8.314 \mathrm{~J} / \mathrm{K} . \mathrm{mol}$ or 0.08206

L.atm/K.mol)

$t$ - retention time (s)

$t$ - thickness of electrode (dm)

$\stackrel{e}{T}$ - solution temperature $(\mathrm{K})$

$V$ - voltage (V)

$V_{H_{2}}$ - Hydrogen volume $\left(\mathrm{dm}^{3}\right)$

$v$ - volume of vinasse $\left(\mathrm{dm}^{3}\right)$

$v_{i}$ - initial volume of vinasse $\left(\mathrm{dm}^{3}\right)$

$v^{\prime}-\frac{d v}{d t}$ $w_{e}$ - width of electrode (dm)

$x$ - Decrease of liquid level (dm)

$z$ - number of electron transfer for Fe (2)

$\alpha$ - kinetic constant $\left(\mathrm{dm}^{3} / \mathrm{mol}\right)$

$\beta$ - kinetic constant $(\mathrm{J} / \mathrm{mol})$

$\Delta H_{s}$ - enthalpy of $\mathrm{Fe}(\mathrm{OH})_{2}$ ionization $(\mathrm{J} / \mathrm{mol})$

$\Delta H_{w}$ - enthalpy of water ionization $(\mathrm{J} / \mathrm{mol})$

$\Delta T$ - increase in temperature $(\mathrm{K})$

$[\mathrm{Fe}]_{\text {sat }}$ - molar of $\mathrm{Fe}^{2+}$ at saturation $\left(\mathrm{mol} / \mathrm{dm}^{3}\right)$

$\left[\mathrm{Fe}^{2+}\right]-$ molar of $\mathrm{Fe}^{2+}\left(\mathrm{mol} / \mathrm{dm}^{3}\right)$

$\left[\mathrm{H}^{+}\right]$- molar of $H^{+}\left(\mathrm{mol} / \mathrm{dm}^{3}\right)$

$\left[\mathrm{OH}^{-}\right]-$molar of $\mathrm{OH}^{-}\left(\mathrm{mol} / \mathrm{dm}^{3}\right)$

\section{References}

1. KERMET-SAID H., MOULAI-MOSTEFA N. Optimization of Turbidity and COD Removal from Pharmaceutical Wastewater by Electrocoagulation. Isotherm Modeling and Cost Analysis. Pol. J. Environ. Stud., 24 (3), 1049, 2015.

2. BUI H.M. Applying Response Surface Methodology to Optimize the Treatment of Swine Slaughterhouse Wastewater by Electrocoagulation. Pol. J. Environ. Stud., 27 (5), 1975, 2018

3. ALI A., SHAIKH I.A., ABID T., SAMINA F., ISLAM S., KHALID A., FIRDOUS N., JAVED M.T. Reuse of Textile Wastewater After Treating with Combined Process of Chemical Coagulation and Electrocoagulation. Pol. J. Environ. Stud., 28 (4), 2565, 2019.

4. SYAICHURROZI I., SARTO S., SEDIAWAN W.B., HIDAYAT M. Mechanistic model of electrocoagulation process for treating vinasse waste: Effect of initial $\mathrm{pH}$. J. Environ. Chem. Eng. 8, 103756, 2020.

5. DEMIRBAS E., KOBYA M. Operating cost and treatment of metal working fluid wastewater by chemical coagulation and electrocoagulation processes. Process Saf. Environ. Prot. 105, 79, 2017.

6. ELAZZOUZI M., HABOUBI KH., ELYOUBI M.S. Electrocoagulation flocculation as a low-cost process for pollutants removal from urban wastewater. Chem. Eng. Res. Des. 117, 614, 2017.

7. TAK B.-Y., TAK B.-S., KIM Y.-J., PARK Y.-J, YOON Y.-H., MIN G.-H. Optimization of color and COD removal from livestock wastewater by electrocoagulation process: Application of Box-Behnken design (BBD). J. Ind. Eng. Chem. 28, 307, 2015.

8. GARCIA-SEGURA S., EIBAND M.M.S.G., DE MELO J.V., MARTÍNEZ-HUITLE C.A. Electrocoagulation and advanced electrocoagulation processes: A general review about the fundamentals, emerging applications and its association with other technologies. J. Electroanal. Chem. 801, 267, 2017.

9. SYAICHURROZI I., SARTO S., SEDIAWAN W.B., HIDAYAT M. Mechanistic models of electrocoagulation kinetics of pollutant removal in vinasse waste: Effect of voltage. J. Water Process Eng. 36, 101312, 2020.

10. YAVUZ Y. EC and EF processes for the treatment of alcohol distillery wastewater. Sep. Purif. Technol. 53, 135, 2007.

11. KHANDEGAR V., SAROHA A.K. Electrocoagulation of distillery spentwash for complete organic reduction. Int. J. ChemTech Res. 5 (2), 712, 2013. 
12. ASAITHAMBI P., SAJJADI, BAHARAK, AZIZ A., RAMAN A., DAUD W., BIN W.M.A. Performance evaluation of hybrid electrocoagulation process parameters for the treatment of distillery industrial effluent. Process Saf. Environ. Prot. 104, 406, 2016.

13. ASAITHAMBI P., SUSREE M., SARAVANATHAMIZHAN R., MATHESWARAN M. Ozone assisted electrocoagulation for the treatment of distillery effluent. Desalination 297, 1\, 2012.

14. AZIZ A.R.A., ASAITHAMBI P., DAUD W.M.A.B.W. Combination of electrocoagulation with advanced oxidation processes for the treatment of distillery industrial effluent. Process Saf. Environ. Prot. 99, 227, 2015.
15. LU J., WANG Z., MA X., TANG Q., LI Y. Modeling of the electrocoagulation process: a study on the mass transfer of electrolysis and hydrolysis products. Chem. Eng. Sci. 165, $165,2017$.

16. GRAÇA N.S., RIBEIRO A.M., RODRIGUES A.E. Modeling the electrocoagulation process for the treatment of contaminated water. Chem. Eng. Sci. 197, 379, 2019.

17. LONE I.H. The Alternative Formulation of Van't Hoff Equation. Phys Chem Ind J 12 (2), 1, 2017.

18. CHOU W.-L., WANG C.-T., HUANG K.-Y. Investigation of process parameters for the removal of polyvinyl alcohol from aqueous solution by iron electrocoagulation. Desalination 251, 12, 2010. 